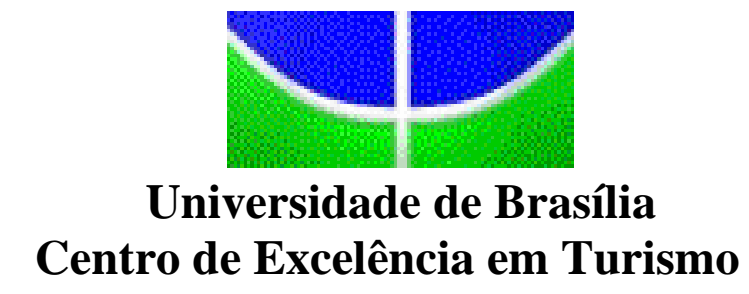

\title{
PARACATU : DAS MANIFESTAÇÕES CULTURAIS DA HOSPITALIDADE AO DESPERTAR DO TURISMO
}

MARLENE GALVÃODA SILVA BARREIROS

Brasília, DF

Dezembro de 2003 
Universidade de Brasília

Centro de Excelência em Turismo

\section{PARACATU : DAS MANIFESTAÇÕES CULTURAIS DA HOSPITALIDADE AO DESPERTAR DO TURISMO}

\section{MARLENE GALVÃODA SILVA BARREIROS}

Orientadora: Professora Doutora Leonor M. Câmara

Monografia apresentada ao Centro de Excelência em Turismo da Universidade de Brasília como requisito para a obtenção do certificado de Especialista em Gestão da Hospitalidade.

Brasília, DF

Dezembro de 2003 
BARREIROS, Marlene Galvão da Silva.

Paracatu: Das Manifestações Culturais da Hospitalidade ao despertar do turismo / Marlene Galvão da Silva Barreiros : Brasília, 2003

$42 \mathrm{f}$. : il

Área de concentração. Hospitalidade

Orientadora: Leonor M. Câmara.

Excelência

Monografia (Especialização) - Universidade de Brasília. Centro de em Turismo, Brasília, 2003.

$307-2008$

BIB / CET

1. Hospitalidade 2. Turismo 3. Cultura 4. Paracatu-MG

Monografia. I. Título.

CDU 338.482.2 : 649.9(043) 
MARLENE GALVÃO DA SILVA BARREIROS

PARACATU: DAS MANIFESTAÇÕES CULTURAIS DA HOSPITALIDADE AO DESPERTAR DO TURISMO

Comissão Avaliadora

Orientadora: Professora Doutora Leonor M. Câmara

Prof. X

Prof. Y

Brasília, DF

Dezembro de 2003 


\section{AGRADECIMENTOS}

Em primeiro lugar agradeço a Deus, pela oportunidade de estar desenvolvendo este trabalho. À minha família pelo incentivo, apoio e tolerância pela ausência, muitas vezes prolongada. À Professora Leonor, Coordenadora do Curso de Gestão da Hospitalidade que gentilmente ajudou na construção deste trabalho. Agradeço a Maria Galvão pela hospitalidade com que me acolheu em sua casa durante todas as fases desta pesquisa, a Doralina Galvão, pelas orações que silenciosamente sei que fez por mim e, em especial, ao paracatuense Antônio D’Abadia de Oliveira Barreiros, pelo companheirismo, apoio incondicional e o carinho com que tenho contado durante os últimos 22 anos da minha vida. 


\section{PENSAMENTO}

“As coisas mais importantes não se aprendem verdadeiramente nos livros, nem nas aulas, nem em conferências, nem em sermões. Passam de pessoa para pessoa através de gestos, de comportamentos concretos. Através de exemplos de vida. Entre essas coisas importantíssimas que não se aprende por meio de palavras, encontram-se as virtudes e os valores. E entre eles está esse tão raro da hospitalidade”.

Paulo Geraldo 


\section{RESUMO}

O propósito deste trabalho é mostrar que a hospitalidade deixou de ser apenas um conjunto de gestos ligados ao saber receber para se tornar uma das forças capazes de influenciar na mudança de conceitos ligados à estrutura da cidade. Juntamente com o turismo, a hospitalidade está ajudando a conscientizar o poder público e a iniciativa privada a repensar alguns aspectos sociais no sentido de enfrentar a acirrada concorrência e os efeitos da globalização da economia. Entre os pontos cruciais a serem enfrentados está a qualificação de pessoal vinculada ao acolhimento. A adoção de políticas públicas e privadas específicas de turismo, eleva o sentimento de orgulho e cidadania da população porque envolve o bem estar social. A cidade mineira de Paracatu conta com mais de dois séculos de história. Pelas condições de sua criação (ponto de parada de tropeiros e arranchamento de bandeiras mineradoras), vivenciou desde cedo a hospitalidade, em diversos tipos de manifestações culturais e orgulha-se da sua rica cultura. De localização privilegiada, boas condições de acessibilidade, grande patrimônio histórico, turístico e cultural, além de estar próxima de grandes centros consumidores como Brasília, Goiânia e outras cidades, reúne reúne as condições para a implantação do turismo profissional. Entretanto, há ainda um grande patrimônio a ser observado: a imagem de cidade e povo hospitaleiros que ostenta. 


\section{ABSTRACT}

The porpouse os the works in the shaw that hospitality left of being only one set of gestures related with knowing how to receive to become one of the forces capable to influence in the change of concepts related o the structure of the city becoming it hospitable. Together with the tourism, the hospitality is helping the public power and the private initiative to acquire knowledge to rethink some social aspects in the direction to face the incited competition and the effect of the globalization of the economy. Between the crucial points it is the entailed qualification of staff to the shelter, ou seja, the agreement of of what means the professional hospitality. The adoption of specific public and private politics of tourism, besides fortifying the feeling of identity and citizenship, through politics of falling of the historic and cultural patrimony, tangible or not. The city of Minas Gerais, Paracatu, counts with more than two centuries of history. For the conditions of its creation (breakpoint of tropeiros and arranchamento of miner flags), it witnessed deeply early the hospitality, in diverse types of cultural manifestations and is proud of its rich culture. Of privileged localization, good conditions of accessibility, great historic, tourist and cultural patrimony beyond of being next to great consuming centers as Brasilia, Goiânia and other cities, seem to congregate the conditions for the implantation of the professional tourism. However, it has a great patrimony to be observed: to use to advantage the image of hospitable city and hospitable people who exhibits. 


\section{SUMÁRIO}

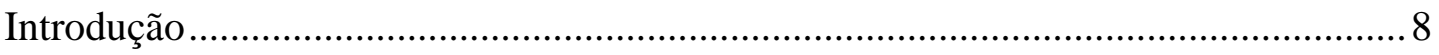

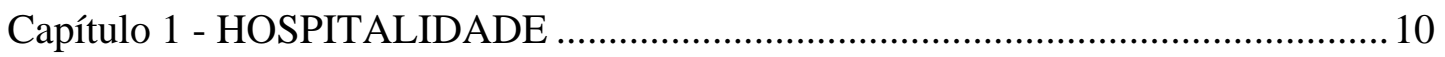

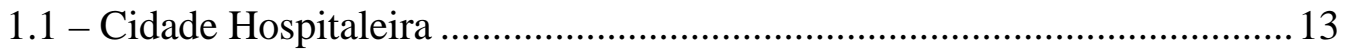

1.2 - Hospitalidade Profissional ....................................................................... 15

1.2.1 - Importância da Qualificação Profissional para a Hospitalidade.....17

1.2.2 - Qualidade Pessoal................................................................... 18

Capítulo 2 - MANIFESTAÇÕES DA HOSPITALIDADE PARACATUENSE .......21

2.1 - Herança Cultural e Intelectual do Paracatuense ..................................... 22

2.2 - A Hospitalidade paracatuense expressa no relato de viajantes ...............23

2.3 - A Hospitalidade paracatuense expressa na literatura regional .................24

2.4 - A Hospitalidade e a família paracatuense................................................26

2.5 - A Hospitalidade paracatuense expressa na religiosidade ....................... 28

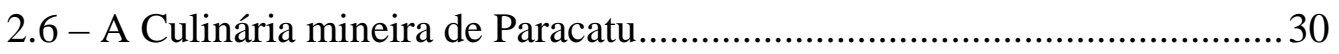

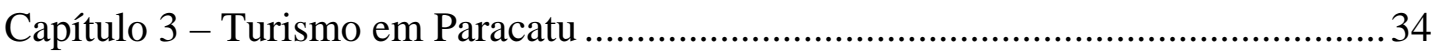

3.1 - O despertar do turismo em Paracatu......................................................... 34

Capítulo 4 - CONSIDERAÇÕES FINAIS E SUGESTÕES …................................37

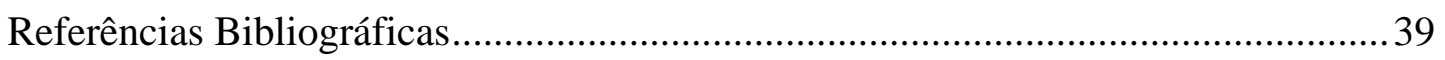

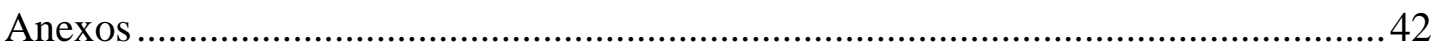

A - Mapa Localização do município de Paracatu

B - Fotografias e folders da cidade 


\section{INTRODUÇÃO}

As manifestações da hospitalidade são tradicionais e pressupõem respeito e amor ao próximo. Revelam a qualidade das relações interpessoais em qualquer instância, seja no atendimento a necessitados de abrigo e alimentação, na família, na religiosidade, dentre outros campos de atuação.

Dentre os diversos tipos de manifestações culturais, a hospitalidade é uma das mais relevantes, principalmente no que diz respeito ao atendimento ao público nas empresas constituintes do trade turístico.

Como todas as áreas do conhecimento, a hospitalidade vem, ao longo do tempo, sofrendo alterações impostas pelas mudanças nas relações sociais e com isso atingindo novas modalidades de ocorrência.

No que diz respeito à vinculação da hospitalidade ao turismo, estudiosos de outras áreas como Geografia, Sociologia, Psicologia, Arquitetura, Urbanismo e outras, vêm se debruçando em pesquisas e descobrindo novos conceitos que transcendem as tradicionais áreas de hospedagem, alimentação e eventos, mantendo a intenção de propiciar bem estar ao outro.

Considerando-se a globalização da economia, o novo perfil de turistas de todo o mundo e seus crescentes níveis de exigências, verifica-se que as práticas da hospitalidade constituem um poderoso diferencial para o desenvolvimento do turismo, principalmente em localidades em fase de implantação desse segmento da economia.

Paracatu mereceu ser alvo da presente pesquisa pela sua ausência nos roteiros turísticos, o que priva o turista, principalmente o brasiliense, de apreciar os inúmeros atrativos turísticos, histórico-culturais, ecológicos e conhecer sua hospitalidade, sua cultura e a culinária mineira, in loco.

Este trabalho é importante para o desenvolvimento do turismo profissional em Paracatu porque propicia aos paracatuenses oportunidade de reflexão sobre a necessidade 
de aliar as tradições culturais da hospitalidade às políticas públicas de turismo, bem como elevar o nível de conscientização de que é preciso qualificar e valorizar os profissionais ligados à área, pois são eles os agentes promotores da hospitalidade na prestação de serviços turísticos e de modo geral.

Esta pesquisa tem como objeto identificar algumas das principais tradições culturais da hospitalidade paracatuense visando a sua possível incorporação na política de turismo ora em processo de elaboração.

É importante a promoção de políticas que resultem em preservação do patrimônio cultural e ambiental e de apoio à iniciativa privada para que sejam acolhidos com simpatia e presteza, primeiramente os próprios habitantes e, depois, os turistas e visitantes de modo geral, utilizando-se das práticas da hospitalidade.

O presente trabalho está dividido em capítulos, sendo os temas apresentados conforme exposição a seguir:

No Capítulo 1 - hospitalidade: cidade hospitaleira; hospitalidade profissional; importância da qualificação profissional para a hospitalidade e qualidade pessoal.

No Capítulo 2 - Manifestações da hospitalidade paracatuense: herança cultural do paracatuense; hospitalidade paracatuense expressa no relato de viajantes; na literatura regional; a hospitalidade e a família paracatuense; na religiosidade e na culinária mineira de Paracatu.

No Capítulo 3 - Turismo em Paracatu e o despertar do turismo em Paracatu; No Capítulo 4 - Considerações finais e sugestões.

A metodologia utilizada no presente trabalho constou de pesquisa bibliográfica em livros; meios magnético (disquete) e eletrônico (internet), e entrevista aberta.

Apesar da relevância do assunto, não se alcançou, por meio dessa investigação, obra específica sobre a hospitalidade paracatuense. Em função dessa dificuldade, utilizou-se como principal fonte de pesquisa algumas obras do professor e historiador paracatuense Oliveira Mello. 


\section{CAPÍTULO 1 - HOSPITALIDADE}

A noção de hospitalidade provém da palavra latina hospitalitas-atis e traduz-se como: o ato de acolher; hospedar; qualidade de hospitaleiro; boa acolhida; recepção; tratamento afável, cortês, amabilidade; gentileza.

Aurélio “ato de hospedar; hospedagem; acolhimento afetuoso.”

Como se vê, a hospitalidade possui diversos sentidos. Por isso, é importante a conceituação e o entendimento da evolução do termo para que se possa perceber as diversas conotações que tem assumido através dos tempos.

A tradição humanística européia define a hospitalidade como um dever moral de qualquer ser humano. O fundamento desse dever está no reconhecimento de que todos temos os mesmos direitos a Terra, o nosso bem maior ${ }^{2}$.

Luiz Octávio de Lima Camargo ${ }^{3}$ : entende que “a noção de hospitalidade coaduna-se com os princípios básicos de todas as religiões e todas elas, sem exceção, têm um lugar de destaque para a idéia de hospitalidade”.

Nas Escrituras Sagradas, o termo hospitalidade está presente em diversas passagens, mostrando exemplos de gestos de acolhimento e amor ao próximo.

No seu livro Não sabíamos que eram anjos: descobrindo o dom da hospitalidade Cristã, Doris W. Greig (1986) ${ }^{4}$ cita: "Uma terceira coisa, que acrescentei para o cristão (e não se encontra no dicionário), é que a hospitalidade envolve "sensibilidade e disponibilidade”. Se não formos sensíveis à oportunidades, não estaremos então disponíveis para elas.”

\footnotetext{
${ }^{1}$ FERREIRA, Aurélio Buarque de Holanda.

2 Artigo Imigrantes somos todos! Da Comunidade de Países Lusófonos, divulgado no site http://imigrantes.no.sapo.pt/indexHospital.html, acesso em 17/9/2003.

${ }^{3}$ Livro Hospitalidade Reflexos e Perspectivas(2002:5-6)

${ }^{4}$ Livro publicado em inglês com título original We Didn’t Know They Were Angels, tradução de Neyd Siqueira. Doris Greig é fundadora, autora e líder do programa Joy of Living Bible Studies.
} 
Para o Arquiteto e Urbanista Lúcio Grinover 5 , "hospitalidade é fundamentalmente o ato de acolher e prestar serviços a alguém que por qualquer motivo esteja fora de seu local de domicílio”.

Da antiguidade até o surgimento da primeira associação do gênero em $1282^{6}$, a hospedagem era quase sempre uma ação de caridade.

A partir daí, conforme explica PIRES (2001:2), os principais proprietários de pousadas de Florença reuniram-se para fundar a primeira associação "grêmio" no sentido de transformar a hospedagem em atividade comercial.

Com o surgimento da ferrovia e da grande hotelaria (século XX), consolida-se o setor hoteleiro com estruturas confortáveis e preocupação com o serviço.

No Brasil, a hospitalidade tem suas origens ligadas ao conceito de ranchos (tropeiros), pousos e vendas, evoluindo mais tarde para estalagens, hospedarias, hotéis e, nos dias atuais (a partir da década de 70), à entrada das grandes cadeias multinacionais hoteleiras.

Hoje, estudiosos de áreas como Administração, Geografia, Arquitetura dentre outras, vêm fazendo novas reflexões sobre o gesto da hospitalidade. Ao atingir o campo do turismo, o estudo da hospitalidade extrapola áreas tradicionais de hospedagem, transporte e outras, englobando questionamentos relacionados à estrutura das cidades no que diz respeito ao bem-estar de seus habitantes.

Nesse sentido, ao se falar em hospitalidade, o espectro de ocupações possíveis é bem mais amplo do que simplesmente hotelaria. O profissional da hospitalidade não é apenas o do hotel e do restaurante, mas também o que atua em todo o sistema receptivo turístico e em órgãos e empresas que, de alguma, forma acolhem os habitantes da própria cidade, observa CAMARGO (2002:9).

\footnotetext{
${ }^{5}$ GRINOVER, Lucio, Hospitalidade e Reflexões e Perspectivas Manole (2002:26).

${ }^{6}$ PIRES, Mário Jorge, Raízes do Turismo no Brasil
} 
Sobre acolhimento na cidade como um todo e a inovação do conceito, a Universidade Anhembi Morumbi, em suas considerações sobre a hospitalidade, aborda entre outros aspectos:

“(...) a hospitalidade implica práticas de sociabilidade, parcerias e serviços que facilitam o acesso a recursos locais e proporciona relações que vão além da interação imediata.

(...) Essa nova visão de hospitalidade pode conduzir a propostas inovadoras de transformação dos conceitos e soluções projetuais adequadas aos novos contextos sociais, econômicos e culturais e aos desafios do novo século, pois tenta relacionar campos da realidade, até hoje estudados por outras ciências aplicadas, reelaborando-os dentro de um novo enfoque; são os campos do turismo, da hotelaria, do lazer do urbanismo, da nutrição e da gestão dos serviços de alimentação, entre outros. “

Manifestando concordância na posição da Universidade Anhembi Morumbi sobre o assunto, a CAPES - Coordenação de Aperfeiçoamento de Pessoal de Nível Superior do Ministério da Educação, no que diz respeito às novas propostas e novos contextos sociais, acrescenta que: “O campo da hospitalidade vem ganhando importância dentro da área de turismo, enquanto estudo das formas de hospedagem, porém ampliando sua abrangência, para outros aspectos, além da infra-estrutura hoteleira, como aqueles relacionados com a infra-estrutura urbana.”

Ao abranger a estrutura das cidades, a hospitalidade tem seu conceito ampliado incluindo-se espaço, identidade cultural, cidadania e outros fatores ligados à qualidade de vida da população.

Qualidade de vida no espaço urbano, conforme assegura SILVA (1997:2002) ${ }^{7}$, é de difícil mensuração. Segundo ele:

“Qualidade no âmbito da cidade é o resultado que combina determinadas características gerais, entre elas segurança, qualidade ambiental, mobilidade e oportunidade de lazer, com sensibilização para as diferenças da população, especialmente as de faixa etária e limitações físicas.”

A adoção das práticas da hospitalidade aplicadas à cidade permite maior interação entre seus habitantes, a iniciativa privada e o setor público, beneficiando-se dessa interação o turismo, que já conta com as tradicionais formas culturais associadas ao gesto de receber.

${ }^{7}$ Apud Dias (2002:65) 
A hospitalidade é um dos temas mais discutidos entre as abordagens culturais relacionadas ao turismo conforme CRUZ (2002:43). Pode-se dizer que o conceito de cidade hospitaleira tradicionalmente conhecido será ampliado, beneficiando-se, com isso, não só turistas e viajantes, mas também e principalmente, os habitantes da própria cidade..

\section{1 - Cidade Hospitaleira}

As expressões “cidade hospitaleira”, "bairro hospitaleiro” e "rua hospitaleira” são tradicionalmente conhecidas e estão vinculadas ao costume coletivo de oferecer hospedagem aconchegante, confortável e deliciosas guloseimas a hóspedes, em determinada localidade. A fim de que esse conceito seja entendido sob novo enfoque, cabe um questionamento: O que é uma cidade hospitaleira hoje?

Pesquisadores e estudiosos de áreas como Administração, Geografia, Arquitetura e Urbanismo dentre outras, asseguram que, para uma cidade alcançar a imagem de hospitaleira, deve propiciar a sua habitante qualidade de vida de modo a elevar o sentimento de orgulho e identidade. Há uma expressão popular que diz: “a cidade que é boa para os habitantes é boa para turistas.”

Existem três características principais que fazem com que uma cidade seja hospitaleira ou não: a legibilidade (o entendimento dos signos, da linguagem de uma cidade), a acessibilidade e a identidade.

A Arquiteta e Urbanista, Zilda Maria Mateus ${ }^{8}$, defende que “a idéia de cidade hospitaleira está vinculada à construção da urbe, à tessitura estrutural e social da cidade como conhecemos hoje”. Ela afirma que:

“(...) Fontes de enraizamento, investimentos reafirmam uma identidade pessoal e coletiva, ambas aliadas a uma nova compreensão de qualidade de vida, fornecendo assim novos parâmetros para a construção de uma filosofia de Cidade Hospitaleira. A união dessas duas concepções, cidade e hospitalidade, leva à formulação também da idéia de Estado, que deixa de ser visto como elemento centralizador”.

\footnotetext{
${ }^{8}$ MATEUS, Zilda Maria, professora e pesquisadora na Universidade Anhembi Morumbi, além de participar de publicações na área de Marketing, Hospitalidade Reflexões e Perspectivas, Manole,( 2002:63-64).
} 
GOUDBOUT (1997) ${ }^{9}$ apud Dias, 2002:29), conceituando hospitalidade, entende:

"A hospitalidade, é um dom do espaço, da habitação, espaço para percorrer a pé ou para contemplação, sendo suas qualidades a superfície, a acessibilidade, o conforto, a estética, a historicidade."Cidade Hospitaleira”, "rua hospitaleira”, expressões da linguagem comum, ilustram bem a doação do espaço, a doação de proteção e segurança, além de abrigo e alimentação".

Percebe-se concordância nas opiniões dos autores citados, uma vez que, para eles, o ordenamento da cidade inclui, principalmente, a preocupação do poder público em propiciar bem-estar social, boa qualidade de vida aos habitantes e pressupõe condições ideais de conforto no acolhimento a turistas e viajantes de modo geral.

Eduardo Yazigi, professor de planejamento do turismo, do Departamento de Geografia da USP, no seu livro [A Pequena Hotelaria e o Entorno Municipal: Guia de montagem e administração], alerta para as exigências do turista, da preferência destes pelos lugares bonitos, confortáveis, por belas paisagens urbanas e rurais. Ainda segundo YAZIGI:

“Pouco adianta criar pacotes turísticos, se turismo e miséria-violência são incompatíveis; (...) De nada adianta sermos excelentes em hotelaria se ao sair à rua o hóspede se depara com a paisagem urbana e natural degradadas, se pode ser assaltado do outro lado rua...”.

A idéia de uma cidade hospitaleira sob o ponto de vista urbano envolve iniciativas que vão além das políticas públicas específicas de turismo. É percebida sob o aspecto urbanístico refletido na preservação do patrimônio, na limpeza das ruas e praças; pela legibilidade e, também, pelo amor que os habitantes demonstram pelo seu lugar.

Outro componente de grande importância a ser considerado na cidade hospitaleira é a informação turística. Ela é essencial ao visitante porque, hoje em dia, as pessoas não dispõem de tempo suficiente para ser gasto à procura de lugares a serem desvendados e caminhos a serem seguidos.

No seu livro Interpretar o Patrimônio: um exercício do Olhar (2002:9-10), MURTA e ALBANO ${ }^{10}$ asseguram que "pouca atenção é dada ao visitante no que se

${ }^{9}$ APUD Dias, (2002:29) 
refere à informação sobre o lugar e seus habitantes, seus hábitos e costumes, sua história e suas lendas (...) para o produto turístico a interpretação é um componente essencial, sobretudo quando se apóia na cultura e em paisagens especiais”

O que dizem as autoras na citação acima é importante porque, além do que foi dito em relação a turistas e viajantes de modo geral, devem ser considerados também os pesquisadores das culturas regionais, da história, dos costumes, das tradições, da gastronomia e de outros assuntos, bem como pesquisadores das cidades como urbanistas e outros. Esses pesquisadores não costumam andar em grupos ou com guias, sendo a informação turística ainda mais importante.

A sinalização adequada, além de dar pistas de que o anfitrião conhece as normas - e é preciso conhecer mesmo -, antecipa os desejos do cliente. É um gesto de hospitalidade que precisa ser confirmado no momento da interação funcionário/cliente, não só por meio de palavras, mas também por gestos.

Se ao adentrar uma cidade, um bairro, uma rua, um estabelecimento público ou privado, o forasteiro obtiver as informações necessárias, indicadas por meio de sinalização adequada, e atendimento com espírito de boa vontade, sem dúvida esse visitante estará pisando numa terra hospitaleira e de um povo espontaneamente hospitaleiro ou treinado para tal finalidade.

\section{2 - Hospitalidade Profissional}

A hospitalidade profissional consiste na formação do indivíduo para que ele seja capaz de prestar atendimento de qualidade ao cliente, visando atingir níveis de excelência nas organizações, ou seja, uma hospitalidade treinada, preparando, especificamente, todos os tipos de estabelecimentos que compõem o receptivo turístico de um lugar, com vistas à satisfação do cliente.

Por exigência da globalização da economia, a acirrada concorrência pela conquista de mercados, além do crescente nível de exigência do turista moderno, os profissionais que

${ }^{10}$ MURTA, Stela Maris e ALBANO. Celina, organizadores Belo Horizonte: ed. UFMG: Território Brasilis(2002:9-10) 
atuam nas áreas de hospitalidade e do turismo necessitam de elevado grau de profissionalismo para estarem aptos a oferecer ao hóspede segurança e informações precisas. Por isso, esses profissionais devem ser treinados.

Nem sempre o anfitrião está recebendo o visitante de forma espontânea. Neste caso, a hospitalidade está associada a uma imposição do trabalho remunerado. Desse ponto de vista, CRUZ (2002:40/43) destaca que a hospitalidade pode ser criada para determinados fins como é o caso da hospitalidade no turismo, considerando-se alguns aspectos:

"Políticos: a criação de alguma hospitalidade voltada a um fim predeterminado (como é o caso da hospitalidade no turismo) envolve tanto ações da iniciativa privada como do setor público.

Alguns dos produtos gerados em função de um possível interesse pela criação de um ambiente hospitaleiro em uma dada escala geográfica (local, regional, nacional) são políticas públicas, que objetivam organizar o setor bem como maximizar seus benefícios.

Políticas gestadas no âmbito do setor privado também podem atuar diretamente na condição hospitaleira de um lugar.

Espacial: (...) a hospitalidade pode ser abordada nos espaços urbano e rural. Ainda sob o aspecto espacial, a hospitalidade tem dimensões diferenciadas em função do vínculo territorial d(s) indivíduo(s) com o espaço: residentes e visitantes ocupam posições diferenciadas.

Essas diferentes naturezas se entrecruzam todo o tempo e a classificação exposta acima não tem outra finalidade senão a de ensaiar uma possível sistematização do conhecimento acerca do conceito de hospitalidade”

Nesse aspecto, pode-se considerar que é necessário “fabricar” profissionais hospitaleiros, uma vez que o seguimento da hospitalidade abrange uma gama muito grande de serviços e requer profissionais devidamente preparados para prestar esse atendimento.

O profissional da hospitalidade deve ir além do desempenho de atividades rotineiras do seu setor e buscar conhecimentos em outras áreas como Arquitetura, Urbanismo, História, Geografia e outras que contribuam para a prestação de informações corretas, tempestivas e satisfatórias ao cliente.

Nesse sentido as entidades educacionais exercem grande influência sobre a formação profissional em hospitalidade voltada para o atendimento a turistas, uma vez que estas funcionam como agentes multiplicadores do conhecimento necessário para o bom desempenho das atividades do setor. 


\subsection{1 - Importância da qualificação profissional para a hospitalidade}

A qualificação profissional a para atendimento nos setores de serviço de modo geral, é importante, pois o profissional bem qualificado tem possibilidade de prestar melhor atendimento ao cliente.

São pouco freqüentes bibliografias programas que contemplam a importância da qualificação profissional voltada para a cultura da hospitalidade e sua importância para o turismo, de modo a cobrir o estudo da cidade hospitaleira em seus novos conceitos.

Sob esse aspecto, os empresários do setor da hospitalidade, por meio de seus setores de Recursos Humanos (Gestão de Pessoal), devem unir esforços para a criação de uma nova mentalidade de treinamento de pessoal visando cobrir essa lacuna.

Para que os empreendimentos estabeleçam diferencial pelos níveis de atendimento, é importante que disponham, em seus quadros, de profissionais devidamente, qualificados e motivados para que o atendimento se dê de forma profissional e humanizada determinando o retorno do cliente.

Outro fator a ser observado é o "momento da verdade" no ato do consumo dos produtos-serviços turísticos. Momento em que o hóspede vai examinar se está recebendo o prometido, com tudo aquilo a que ele tem direito, se os seus desejos, suas necessidades e suas expectativas foram atendidas e se foi compensado por aquilo que pagou no momento da contratação do serviço (CASTELLI, 2002:132) ${ }^{11}$. Considerando-se que os estabelecimentos estão sempre expostos à avaliação do cliente, CASTELLI adiante, afirma que não é suficiente satisfazer as exigências do cliente, é preciso fazer melhor do que os concorrentes, ou seja, é preciso encantá-lo.

Embora desejosas de conhecer lugares e culturas diferentes ou por qualquer outra razão que tenha motivado o afastamento de casa, as pessoas querem ser compensadas, de alguma forma, quando estão hospedadas.

\footnotetext{
${ }^{11}$ CASTELLI se refere especificamente ao produto hoteleiro.
} 
O estabelecimento deve dispensar atendimento de boa qualidade e com personalização no trato além de presteza e simpatia. No mínimo, deve cumprir com tudo o que prometeu.

Tanto empresários, quanto gestores, como profissionais, devem estar cientes de que o sorriso no rosto e beleza física são importantes, mas não suficientes para prestar bom atendimento. É necessário profissionalismo.

Essa também é a idéia dos autores Francisco Flávio de A. Rodrigues, Maria Leonor de M. S. Leal e Lourdes Hargreaves ao elaborarem o livro Qualidade em Prestação de Serviços. Acrescentam que os trabalhadores vêm-se tornando parceiros do trabalho e, com isso, sendo valorizados pelas empresas.

“O trabalhador precisa saber que atender à expectativas do cliente não é tarefa difícil! Basta querer e, logicamente, estar capacitado para fazê-lo.

Os atuais especialistas em administração são unânimes em afirmar que pessoas amistosas, cordiais, educadas e competentes, quando prestam um serviço, são muito mais valiosas do que a mais sofisticada tecnologia.

E por que podemos afirmar isso?

Justamente porque o atendimento na prestação de serviços é realizado por pessoas, trabalhadores da empresa, e não por máquinas! Máquinas não dialogam, não sabem ouvir e argumentar, não negociam, não lidam com o emocional e o afetivo, através de atitudes, comportamentos, enfim, não estabelecem o nível de relação de que o cliente precisa para se sentir plenamente atendido e satisfeito.”

Sendo assim, acredita-se que os gestores de pessoas, ao utilizarem técnicas adequadas de recrutamento e seleção de pessoal e adotar um treinamento voltado para a hospitalidade e o turismo, estarão alcançando um diferencial competitivo capaz de enfrentar a grande concorrência verificada na corrida pelos mercados consumidores e, ao mesmo tempo, conscientizando-se de que essas mudanças passam pela qualidade pessoal.

\subsection{2 - Qualidade Pessoal}

A qualidade da prestação de serviços percebida pelo cliente depende, substancialmente, das pessoas que a executa, porque são elas que viabilizam o alcance da finalidade da empresa. Sendo assim, consideram-se como questões mais importantes na gestão de pessoas: a organização do trabalho, a escolha e o preparo das pessoas para sua realização e o acompanhamento dos resultados. 
Sobre a importância da qualidade das pessoas na prestação de serviços, JACOCCA (apud, CASTELLI, 2002:59) ${ }^{12}$ afirma:

“A chave de uma gestão bem-sucedida não é a informação, e sim as pessoas, os colaboradores. Ou ainda: em última instância, o conjunto de atividades empresariais pode ser reduzido a três palavras: pessoal, produto e benefícios. A prioridade corresponde ao quadro de colaboradores. A menos que se disponha de uma equipe eficiente, de pouco servem os outros dois elementos”.

Em concordância com a posição defendida por JACOCCA, CASTELLI entende que:

“A Qualidade está nas pessoas. São elas que nos serviços hoteleiros fazem a diferença e ocupam lugar de destaque. Os equipamentos, instalações e tecnologia ficam em segundo plano. Em vista disso, é preciso que o hotel disponha, em seus quadros, de funcionários que tenham, simultaneamente, conhecimentos, habilidades e atitudes pertinentes e estejam suficientemente motivados para realizarem o seu trabalho. Até porque um funcionário pode saber fazer um determinado serviço, mas, se não possuir atitudes adequadas ou não tiver vontade para fazê-lo, põe tudo a perder. É preciso, pois, que ele também queira fazer o trabalho bem feito. Inclusive com cortesia, educação, empatia e emoção, ingredientes essenciais das prestações hoteleiras. Isto, só pessoas podem fazer”.

Destaca, ainda, que "a qualidade pessoal é a base de todas as outras qualidades". (CASTELLI, 2002: 60).

No pensamento de YAZIGI (2001), essa é a postura que os empreendimentos, de menores portes podem adotar para que angariem diferencial competitivo frente às grandes redes hoteleiras que vêm se estabelecendo em todo o mundo.

“... o único modo de enfrentar os trustes hoteleiros consiste, justamente, em oferecer aquilo que eles não conseguem praticar muito bem, devido ao seu volume de passantes, senão se perderiam a personalização do trato. (...) é nesse sentido que a pousada ou pequeno hotel, com suas atmosferas íntimas e de relação muito pessoais, se configuram como opções aos que buscam um estilo diferente de se hospedar, mais familiar, econômico, menos variado em serviços, mas não necessariamente com qualidade inferior”.

Com um mercado altamente competitivo, que tem como objetivo principal a busca da qualidade por meio da satisfação do cliente, os gestores de pessoas têm cada vez mais necessidade de observar o perfil do profissional a ser contratado, bem como a importância da capacitação profissional e da valorização pessoal, pois a qualidade na prestação de

\footnotetext{
${ }^{12}$ Lee Jacocca em seminário internacional realizado em São Paulo, 1993.
} 
serviços depende de cada trabalhador, se este estiver consciente do seu papel e suficientemente comprometido com o empreendimento. 


\section{CAPÍTULO 2 - MANIFESTAÇÕES DA HOSPITALIDADE PARACATUENSE}

A Cidade de Paracatu, situada no noroeste do estado de Minas Gerais, surgiu sob a influência do ouro no início do século XVIII.

A localidade, que já era ponto de parada de tropeiros que iam abastecer a região mineradora de Goiás, acolheu também duas grandes bandeiras mineradoras: a do mineiro de São João Del Rei, Felisberto Caldeira Brant, proveniente das minas de Goiás e a do paulista José Rodrigues Fróis, oriunda das bandas da Bahia. Do cruzamento dessas grandes penetrações que ocorreram em Minas Gerais: as boiadas (ciclo do couro) e as bandeiras (ciclo do ouro) iniciando-se a formação dos primeiros núcleos povoadores da região.

Esta localidade transformou-se no "Arraial de Santana das Minas do Paracatu” que, em 1745, constituía-se de oitenta e cinco por cento de escravos, com predominância de negros oriundos da Costa da Mina, sudaneses, portanto (OLIVEIRA MELLO, 2002:81).

O ano de 1744 marca a data oficial dessas descobertas, sendo oficialmente reconhecido como seu descobridor, José Rodrigues Fróis.

Em 20 de outubro de 1798, foi criada a Vila de Paracatu do Príncipe, por alvará de D. Maria I (a Louca). Em 1840, a Vila foi elevada A cidade; era o maior município da então província de Minas Gerais.

Durante algum tempo, o ouro dos depósitos de aluvião foi abundante e atraiu aventureiros de outras localidades na expectativa de riqueza fácil. O arraial experimentou rápido desenvolvimento, ocorrendo depois o declínio do precioso metal.

O declínio produtivo do ouro de aluvião provocou a decadência econômica da Vila de Paracatu tornando-a isolada até meados do século XX. Com a construção de Brasília, a região de Paracatu, beneficiada pela sua localização às margens da BR 040 que liga Brasília a Belo Horizonte, retomou seu crescimento.

Hoje, o Município de Paracatu é destaque, em Minas Gerais e no Brasil, pela sua moderna e expressiva produção de grãos e de ouro, utilizando-se das mais avançadas tecnologias disponíveis no mercado. Transformada em pólo de desenvolvimento e 
escolhida como sede da administração regional pelo Governo do Estado, busca o progresso e a modernidade. Simultaneamente, trabalha a efetiva valorização de suas origens e de seu passado.

\section{1 - Herança Cultural e Intelectual do paracatuense}

Apesar do isolamento que a cidade de Paracatu viveu após o declínio da produção de ouro de aluvião, OLIVEIRA MELLO (2002:248-250) afirma que os primitivos do arraial não deixaram de lado a instrução de seus filhos. Isso fez com que Paracatu se celebrizasse e fosse respeitada como terra culta, dentro do conceito de cultura: “melhoria intelectual, refinamento do saber”. Acrescenta que os filhos das pessoas mais abastadas, ao superarem o ensino oferecido em Paracatu, eram transferidos para os colégios do Rio de Janeiro, e de lá para Coimbra.

Afirma, ainda, que “a vida intelectual em Paracatu, pelo que está visto, é fundada sobre o lastro da cultura que data das aulas-régias, a partir de 1773 e, antes disso, vigários e capelães foram os primeiros mestres-escolas”. Em entrevista a Florival Ferreira do jornal O Movimento diz:

“...Acompanho a cultura de Paracatu desde o início, porque não é uma manifestação que nasceu da noite para o dia. Ela é marcante, bicentenária, tendo sofrido influência dos portugueses, dos africanos, dos paulistas e dos nordestinos. Então, temos uma cultura onde estão mescladas influências do sul e do nordeste do Brasil, e também da África e de Portugal. Trata-se e uma cultura que foi construída no isolamento, permanecendo intocada por um longo tempo. Até 1960, Paracatu era um oásis de cultura no Noroeste de Minas Gerais.

Costumo dizer que Paracatu nasceu dos passos lerdos do boi, do couro, para transformar-se na famosa aglomeração no Século XVIII, com o ouro (retirou-se o C) e fixar-se na parte cultural e formativa. Já no século XVIII, constatamos essa preocupação cultural, com o padre Domingos Simões da Cunha e a Casa da Ópera, na Rua do Ávila, além do Teatro Philodramatico, infelizmente demolido em 1952. (...) a cultura de Paracatu permanece ativa.

É claro que a cultura de Paracatu permanece de forma diferente. Brasília fez com ela deixasse de ser aquele oásis. E depois chegaram os japoneses, gaúchos, holandeses, cada um influenciando a atividade cultural”.

Outra fonte sobre as origens culturais, dos costumes e tradições de Paracatu é o vídeo documentário/ficção ${ }^{13}$ que mostra a epopéia da exploração do ouro na antiga mina de Paracatu, denominado "Morro do Ouro Ambição e Agonia”, escrito e produzido pelo paracatuense Lavoisier Wagner Albernaz (1992), com apoio do CPCE - Centro de Produção Cultural e Educativa da Universidade de Brasília.

\footnotetext{
${ }^{13} \mathrm{O}$ vídeo referenciado foi produzido com base na história real sendo os artistas os próprios paracatuenses.
} 
Esse filme retrata os primórdios de Paracatu, referindo-se à cidade como "a velha Atenas Mineira”14 . Essa produção mostra também a miscigenação do branco, do índio e do negro e mostra a hospitalidade vivida na Vila de Paracatu do Príncipe, bem como a exploração do atual ciclo da mineração do ouro em Paracatu.

Paracatu é berço de personalidades que se destacaram em diversas áreas do conhecimento científico, como Francisco de Melo Franco, primeiro puericultor brasileiro; o padre Domingos Simões da Cunha com destaque para a poesia e para a música. Muitos outros nomes de ilustres paracatuenses podem ser citados como contribuintes da sua intelectualidade, a exemplo do Professor Olympio Gonzaga, o primeiro escritor de Paracatu $^{15}$.

Já no século XIX é mencionado o nome do poeta paracatuense Afonso Arinos. Seu nome consta como um dos mais expressivos da literatura regional brasileira que adere ao sertanismo literário. É do Noroeste de Minas através de Pelo Sertão, de Afonso Arinos, que surge o autêntico regionalismo literário brasileiro, afirma OLIVEIRA MELLO.

\section{2 - A hospitalidade paracatuense expressa nos relatos de viajantes}

Em princípios do século XIX, os estrangeiros, em viagem de reconhecimento, contaram com a hospitalidade de pequenos arraiais, vilas e cidades do interior do Brasil.

Como anfitriã nessa oportunidade, Paracatu acolheu o primeiro viajante estrangeiro a dar entrada no planalto central, o naturalista austríaco Johann Emanuel Pohl (BERTAN, 2000:202-203) ${ }^{16}$

14 (...) Desde os primórdios, Paracatu destacou-se no cenário mineiro por sua expressão cultural e intelectual (...) Paracatu de ontem é carinhosamente mantida pela Paracatu de hoje. Eloqüente demonstrativo dessa tradição é o fato de antes de ser proclamada a Independência do Brasil haver sido criada em Paracatu a cadeira de Retórica e Filosofia, pelo Decreto Régio de 17 de maio de 1821. Assim foi a Vila de Paracatu do Príncipe, a primeira localidade do interior a ter uma Cátedra Oficial de Filosofia. Daí ter sido agraciada com o honroso título de "ATENAS MINEIRA"

15 Olympio Gonzaga, é o pioneiro na compilação da história paracatuense, marcando época na historiografia mineira. É autor da obra Memória Histórica de Paracatu, muitos artigos pela imprensa regional e algumas árvores genealógicas de famílias paracatuenses publicadas em revistas especializadas. (Oliveira Mello, 2002:293)

${ }^{16}$ O primeiro viajante estrangeiro a da entrada no Planalto foi o Dr Johann Emanuel Pohl, médico, súdito austríaco nascido na atual República Tcheca, formado na Universidade de Praga. Veio na comitiva nupcial 
“...ao chegar ao Planalto em dezembro de 1818, tinha 37 anos, quando vamos encontrá-lo, já em Paracatu, vindo de São João Del Rei pela velha picada de Goiás (...) Sobre a qualidade de hospitaleiro atribuída ao paracatuense, o Dr. Pohl pronunciou em seu livro intitulado Viagens ao Interior do Brasil, de 1823, reeditado pela USP/Itatiaia, do qual consta:

"Exalto grandemente a cortesia dos habitantes. Vai a ponto de, por exemplo, não passarem diante da casa do Capitão-Mor sem já de longe tirarem o chapéu (...). Tive a oportunidade de assistir a uma festa de batizado. O pai da criança veio buscar-me em traje de gala, espada de aço com faixa de seda rubro-anil à cinta, solenemente...”

OLIVEIRA MELLO (2002:88) também registrou o comentário de Pohl acerca da hospitalidade paracatuense ${ }^{17}$. Acrescenta que outro viajante estrangeiro, Auguste de Saint-Hilaire, esteve na região e comentou seu ponto de vista sobre a hospitalidade paracatuense como anfitrião:

"Durante a estada que tive nessa vila, fui cumulado de gentilezas pelo Sargento-Mor Alexandre Pereira e Castro, que pusera sua casa à minha disposição, e fora se alojar na vizinhança e também me prestou mil pequenos serviços. Seria impossível encontrar homem melhor: bastante ativo, embora não fosse mais um jovem, sempre alegre, sempre pronto a obsequiar, sempre disposto a desculpas aos outros e a tomar o partido da moderação”

Vê-se que as características consideradas da boa hospitalidade (cortesia, gentileza, modo agradável de receber e servir), vivenciadas pelos viajantes do século XIX, continuam sendo valores fundamentais, que devem ser cultivados por qualquer comunidade, em especial por aquelas que têm interesse em desenvolver o turismo profissional.

\section{3 - A hospitalidade paracatuense expressa na literatura regional}

Um dos mais expressivos nomes da literatura regional brasileira, o paracatuense Afonso Arinos, viveu fora da cidade de Paracatu e do Brasil, mas sempre demonstrou amor ao seu país, à sua cidade natal. Ao retornar da Europa, em visita a Paracatu, na segunda metade do século XX, revive a hospitalidade paracatuense, dessa vez como hóspede.

Como visitante, ao aproximar-se daquela paisagem tão familiar conta (OLIVEIRA MELLO, 1975:119-120):

“... A uma légua, na praia de São Domingos, grande quantidade de amigos e conterrâneos, em luzida cavalhada o aguardava. De lá a comitiva o acompanharia até à Cidade (...) Mais um pouco de

de D. Leopoldina, filha do imperador da Áustria, a infeliz primeira mulher de nosso futuro imperador Pedro I.

- O professor Olympio Gonzaga é autor da obra Memória Histórica de Paracatu, Uberaba, Typ. Jardim, 1910, referenciado por Bertran (2000:104), como “o Herôdotos paracatuense”

${ }^{17} \mathrm{O}$ teor do comentário citado pelo autor tem o mesmo teor daquele citado por Bertran. 
viagem e estaria pisando as ruas enrugadas de Paracatu. Lá chagando, além da comitiva que fora ao seu encontro, uma multidão o aguardava no Largo da Abadia, na entrada da cidade. Era uma homenagem popular, espontânea, sincera, que o comoveu. Homenagens que, dizia ele, tributadas apenas ao Ouvidor ou a Bispo. A multidão o acompanhou até a Rua Goiás, onde ficava o antigo sobrado de seu primo afim o tabelião Antônio de Sousa Gonçalves e onde se hospedaria. (...) surgiu Miguel Catita. Seu afilhado de batismo.

Meu padrinho, está pronto o banho.

Nada melhor para o homem que se encontrava cansado depois da travessia da Fazenda do Saco até Paracatu. Diante daquele convite, encontrou uma evasiva para despedir-se dos amigos e recolher-se um pouco. Entrou no quarto e encontrou duas grandes bacias burnidas, com água tépida e cristalina.

- $\quad$ Para que duas bacias, Miguel?

- $\quad$ Uma é para lavar e outra para enxaguar - respondeu-lhe o afilhado.

(...) Depois do banho, contou o fato como uma das melhores pilherias daquele dia.

Tanta homenagem, tanto carinho, tanto cansaço, mas a ânsia de percorrer toda a cidade não lhe permitiria o descanso após tão exausta viagem”.

Em outra passagem na mesma ocasião, verifica-se a prática da hospitalidade através do costume da gastronomia. A simplicidade de Arinos estava evidenciada na ternura de Josefão, exescrava do dr. Joaquim Pedro de Melo. Percebe-se a hospitalidade na seguinte passagem como era de costume em Paracatu.

“..Josefão já o procurara para uma visita e um agrado ao "nhonhô dotô”. No entanto, não se encontrava em casa. Lá fora de volta... para surpresa de ambos, Josefão depara-se com Arinos já entrando no Beco de siô Quim, descendo que vinha da rua da Praça. Josefão levava na mão o leite, num caneco esmaltado, coberto por um pires com biscoito de "goma”. Voltava com o agrado para casa, pois ela mesma o queria entregar ao "nhonhô dotô" e ter a felicidade de vê-lo saboreá-lo.

- $\quad$ Oi, nhonhô dotô, fui levá esse objeto pro sinhô e o sinhô num tava in casa.

- $\quad$ Que é isso, Josefão?

- $\quad$ É um copo de leite e uns biscoitos de "goma” que a preta veia arrumo pra agrada o nhonhô.

Pois então me dá, Josefão. Fico muito satisfeito com a sua delicadeza e como aqui mesmo”.

Durante a estada de Arinos em Paracatu, as manifestações de hospitalidade continuaram em outras modalidades como a música e a dança.

Esse gesto de delicadeza (ir, em comitiva, ao encontro do visitante para dar boas vindas) era comum na Paracatu do século XVIII. Perdurou por muito tempo, até mesmo quando o automóvel ainda era novidade na região (1947), como manifestado por Afonso Arinos (sobrinho), em seu comentário sobre a amabilidade do povo paracatuense (terra de seus avós), ao ser recebido no porto do Pontal:

"No alto desse pequeno desembarcadouro, calçado a pé-de-moleque, o que fomos encontrar, chefiada pelo gordo Dudu Rocha, a comitiva de amigos que, cientes da nossa chegada, tinham vindo de Paracatu aguardar-nos na divisa do município.

Dudu Rocha talvez não atentasse, na era do automóvel, um delicado costume de Paracatu, do tempo de nossos avós, o costume dos cavalheiros, que seguiam o viajante até o primeiro pouso, ou nele vinham esperá-lo, quando de regresso. Meu tio Arinos recorda essa tradição na página intitulada A árvore do Pranto." ${ }^{18}$

${ }^{18}$ Nas imediações de Paracatu, havia uma árvore, onde se faziam as despedidas dos viajantes e a que o povo apelidara, de "Pau do Choro" (Oliveira Mello, op cit p.320),. segundo ele, Afonso Arinos imortalizou o "Pau do Choro" (por ele crismado de Árvore do Pranto) in Histórias e Paisagens. Rio, Livraria Francisco Alves, 1971, p.57-62. 
Ainda sobre a hospitalidade do paracatuense, quando da visita da comitiva do Embaixador e Jornalista Assis Chateaubriand em 1949, assim percebeu a hospitalidade do paracatuense: “As famílias conhecem tão bem a arte de receber quanto os mais finos anfitriões de São Paulo e Rio”19.

\section{4 - A hospitalidade e a família paracatuenses}

A família é uma instituição que exerce grande influência sobre a sociedade. Vem desempenhando não só o papel primordial que lhe é conferido - o da reprodução da espécie - mas também abraça outras missões como a socialização dos filhos, a manutenção das tradições culturais e a preservação dos valores sociais.

Os laços familiares são mantidos mesmo nos grande núcleos populacionais em que os costumes já se afastaram da forma patriarcal ou semipatriarcal, mesmo porque, a partir do final do século XIX, as condições sociais assim exigiam em função de determinantes de cunho social e econômico como o ingresso da mulher no campo de trabalho e a igualdade de tratamento da filha em relação ao filho dentre outros aspectos.

A relação familiar é uma das formas de manifestação da cultura a que se atribui grande importância visto que na família nasce e floresce a cultura de modo geral. Os pais ensinam com naturalidade, aos filhos aquilo que vivenciam. Assim, são repassados os gestos da hospitalidade.

Pode-se considerar hospitaleira a família que, além dos laços consangüíneos, age como amigos solidários, seus membros respeitam uns aos outros enquanto, por meio de atitudes, transformam o lar em um lugar acolhedor e harmônico.

O conceito de hospitalidade ligado à família é valorizado não só em Paracatu, mas em todo o mundo. Trata-se de princípio muito mais abrangente. Para exemplificar,

${ }^{19}$ OLIVEIRA MELLO, Antônio de (2002: 88) 
observa-se o artigo publicado sobre a hospitalidade mexicana. O artigo "Mujer em

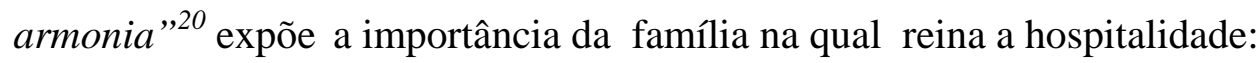

\section{“(...) PRIMERO LOS DE CASA}

Todo acto de servicio que se hace a um miembro de la família com el toque de la hospitalidad se constituye realmene em un acto que constuye el hogar y lê permite permanecer nido y armónico e través del tiempo. Por esto es esencial la hospitalidad em casa, "para los de casa"(...) La hospitalidad es, fundamentalmente, una actitud para con los propios, los nuestros, las personas que que queremos y con quienes compartimos nuestra vida. Hospitalaria es unamujer cuando recibe con cariño a su esposo; hospitalario es el marido cuando compreende el cansacio de su esposa y la ayuda con los quehaceres diarios, la atiende com cuando eran novios, y le muestra que, ante todo, es la reina desl hogar; hospitalarios son los hijos cuando recibem a sus padres con alegrya y afecto, cuado com su comortamiento se convierten en los mejores hospederos de sus padres. Hospitalarias es toda la familia cuando el clima de respeto y confianza seguridad. Entonces, cuando reciben a los de afuera, a quienes están de paso, toda esa hospitalidad natural se conviert en un regalo para el visitante, que tratado por todos como el huésped de honor."

Nesse sentido entende-se que é da hospitalidade familiar que dependem as demais modalidades desse fenômeno cultural e irradia-se para outras instâncias das relações interpessoais.

Sobre a família paracatuense, OLIVEIRA MELLO (2002:87), ao elencar as características do paracatuense, assim se expressa:

“... na sua sistemática de vida, o paracatuense não deixa de ser um povo um tanto fechado, mas hospitaleiro, cortês, solidário e apegado à família.

(...) Dentro da própria contextura familiar é um povo discreto no seu viver, extrapolando aos que com ele convivem. É solidário por excelência, detendo grande domínio sobre si mesmo a ponto de, exteriormente, ser considerado um povo frio".

Um povo um tanto fechado ${ }^{21}$. Trata-se de característica do mineiro de um modo geral. “... os mineiros são mais conservadores do que a média das outras populações

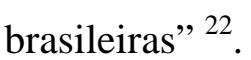

Como extensão da família, a escola sempre contribuiu de forma marcante para a manutenção de padrões e atitudes de comportamentos e influencia na socialização do cidadão paracatuense, de modo a influir nas tendências da hospitalidade por meio da interação e da formação dos princípios de cidadania.

\footnotetext{
${ }^{20}$ Artigo La hospitalidad, divulgado no site http:/www.terra.com.mx/MujerEnArmonia/articulo/115713/ acesso em 16/9/2003.

${ }^{21} \mathrm{O}$ autor provavelmente referere-se à característica de conservador atribuída ao povo mineiro.

${ }^{22}$ Nova Enciclopédia BARSA Vol 10 p.42
} 


\section{5 - A hospitalidade paracatuense expressa na religiosidade}

A hospitalidade paracatuense está presente na religiosidade por meio de diversas ações desenvolvidas pela Diocese de Paracatu, através da Paróquia Santo Antônio, em conjunto com outras instituições como o Juizado de Menores.

Em entrevista a autora deste projeto, na sede da Paróquia Santo Antônio, o Monsenhor Benedito Gonçalves dos Santos disse que “a Paróquia de Santo Antônio tem procurado desenvolver um trabalho social em todas as áreas”.

Sobre o acolhimento, Monsenhor falou de vários projetos sociais, dentre eles a construção da Casa do Peregrino e outros projetos conforme a descrição abaixo:

- Casa do Peregrino ${ }^{23}$ - visa acolher os peregrinos vindos de outras cidades oferecendo-lhes hospedagem, alimentação e trabalho comunitário, auxiliando-os a seguirem sua jornada; pais paracatuenses carentes, principalmente aqueles que estão desempregados; ressocialização de presos e apoio às famílias destes; dentre outras.

- Pastoral da Criança - atendimento aos meninos de rua, dando cursos profissionalizantes; acolhimento e informação a mães gestantes oferecendo meios para que o filho tenha crescimento normal.

- Grupo de Luz de Vida $^{24}$ - recuperação de dependentes químicos e alcoólatras (fazenda a $60 \mathrm{~km}$ da cidade); acolhimento e condições para que a pessoa se liberte do vício. Ao mesmo tempo é oferecido pela Casa do Peregrino atendimento à família da pessoa que está em tratamento.

\footnotetext{
${ }^{23}$ O projeto Casa do Peregrino está em fase de implantação, com previsão de conclusão para dois ou três meses. Consta de uma construção ampla com cerca de $500 \mathrm{~m} 2$ e com previsão de 10 quartos, alas masculina e feminina.

${ }^{24}$ Este projeto teve início em 1986 e a previsão para o acolhimento é de nove meses, (o período de uma gestação). Daí a denominação “Luz de Vida” .
} 
- Orfanato - Casa de amparo às crianças órfãs, e atendimentos a gestantes carentes; são pessoas que geralmente não têm uma família estruturada.

- Asilo São Vicente - é um conjunto de casas estruturadas para acolher os idosos carentes e deficientes que não têm amparo familiar.

Na entrevista, a questão do turismo em Paracatu também foi abordada pelo Monsenhor. Segundo ele, existe o desejo de a Igreja participar do turismo, abrindo as portas dos templos para receber turistas, pois tratam-se de igrejas famosas devido à riqueza dos detalhes dos trabalhos arquitetônicos. Destacou, ainda, que estão sendo feitos treinamentos de crianças para que elas possam monitorar os turistas em diversos pontos de Paracatu, principalmente nos dois templos religiosos.

Conforme os ensinamentos das Sagradas Escrituras, Paracatu tem demonstrado que vive a hospitalidade cristã, seguindo os exemplos de diversas passagens bíblicas que exemplificam o acolhimento como forma de amor ao próximo. Verifica-se essa semelhança, ao comparar algumas das ações desenvolvidas pela Paróquia Santo Antônio, em Paracatu, com o gesto de Abraão referido em GÊNESIS 18:1-8):

"O Senhor apareceu a Abraão nos carvalhos de Mambré, quando ele estava assentado à entrada de sua tenda, no maior calor do dia. Abraão levantou os olhos e viu três homens de pé diante dele. Levantou-se no mesmo instante da entrada de sua tenda, veio-lhes ao encontro e prostrou-se por terra. "Meus senhores, disse ele, se encontrei graça diante de vossos olhos, não passeis avante sem vos deterdes em casa de vosso servo. Vou buscar um pouco de água para vos lavar os pés. Descansai um pouco sob esta árvore. Eu vos trarei um pouco de pão, e assim restaurarei as vossas forças para prosseguirdes o vosso caminho; porque é para isso que passaste perto de vosso servo” Eles responderam: "Faze como disseste.” Abraão foi depressa à tenda de Sara; "Depressa, disse ele, amassa três medidas de farinha e coze pães." Correu em seguida ao rebanho, escolheu um novilho tenro e bom, e deu-o a um criado que o preparou logo. Tomou manteiga e leite com o novilho preparado, conservando-se de pé junto deles, sob a árvore, enquanto comiam".

Abraão não se limitou a fornecer hospedagem e alimentação a seus hóspedes. Naquele momento, somaram-se à oferta de alimentação e pouso para descanso outros componentes como a disponibilidade, a sensibilidade, o carinho com que Abraão os atendeu. São detalhes que fazem diferença em qualquer relacionamento interpessoal.

Esses detalhes também foram observados por GREIG (1996:51) em sua análise sobre o gesto de Abraão:

“Abraão mostrou um coração de servo, quando pediu que repousassem à sombra da árvore e foi buscar água para lavar os pés deles. Foi sensível ao cansaço dos visitantes e insistiu para que 
ficassem por algum tempo antes de continuar a jornada. (...) Abraão não só os convidara para ficar e repousar antes de continuar seu caminho, mas que o velho voltara rapidamente à tenda para encorajar Sara a preparar a melhor comida para as visitas enquanto ele corria até o rebanho e escolhia um novilho gordo para a refeição. Ao que parece, ele serviu aos estrangeiros o melhor que tinha”

Pelo que se vê, o dom da hospitalidade cristã se dá de forma espontânea. Paracatu não se limita a prestar orientação espiritual. O gesto de receber peregrinos que passam em Paracatu e acolhê-los, sem se preocupar a quem está ajudando, revela o dom da hospitalidade.

\section{6 - A Culinária mineira de Paracatu}

A culinária mineira tornou-se uma identidade para o estado e vem ganhando aceitação nacional e internacional. Assim como a cultura de modo geral, a culinária originou-se do encontro do índio que já conhecia a mandioca, o mel e outros ingredientes que a terra ofertava, com o negro que deu a sua contribuição e com o português que sentiu a necessidade de se adaptar aos produtos da terra.

Após o declínio do ouro, surgem os pomares e a criação de gado; vem um tempo de fartura de leite, ovos e frutas. A culinária vai se desenvolvendo geração após geração. Nas regiões mais pobres, a quitanda preferida é o biscoito de polvilho, a farinha de milho, que era servida com feijão inteiro ou com café; nas regiões mais ricas, onde havia fartura de leite, surge o queijo minas. Mais tarde, o biscoito de polvilho é misturado ao leite e ao queijo, surgindo o famoso pão de queijo, símbolo da mineiridade.

Consoante BERTRAN (2000: 177), a culinária mineira é semelhante à goiana, desde a escolha dos produtos, às características da preparação dos alimentos. Diverge-se em alguns detalhes:

“(...) De Goiás exportaram-se algumas modas para a culinária do Triângulo Mineiro e de lá importaram-se ouras (pertenceu a região ao bispado de vila Boa de Goiás por dois séculos) e os padres goianos, pastores dos vilarejos surgentes, por certo sugeriram às matronas preocupadas em obsequiar os pobres curas do sertão, o gostinho, a forma de fazer acepipes que lembrassem do lar remoto (...) a culinária mineira e goiana divergem em detalhes e em alternativas combinantes, parecendo-nos que devem pouco às tradições africanas e pouco às indígenas.

Provêm, ambas de uma raiz exótica no norte de Portugal. Segundo Oliveira Marques, pra ali chegaram, em algum momento dos anos 1500, sementes de milho entre o Douro e o Minho e nos anos 1600 suplantaria o plantio imemorial de cevada e aveia, e lançaria os fundamentos para uma nova civilização culinária euro-americana” uma civilização o milho, importada e amalgamada na Lusitânia e então reexportada ara o Brasil junto com o português. Colonial nortenho, vindo para 
as minas brasileiras no século XVIII (...) uma civilização do milho ? Por que? Porque resulta num delírio protéico fundado no trinômio vegetal inocente do milho, mandioca e abóbora, como até a pouco anos se plantava e se comia nas roças e coivaras de todo o Brasil Central”.

Sobre a especificidade da cozinha paracatuense, OLIVEIRA MELLO (2002:321323), no que diz respeito à culinária, afirma que Paracatu tem as mesmas características da culinária mineira de modo geral, com algumas diferenças:

“A cozinha paracatuense possui algumas novidades que lhes são próprias, como o molhode-banana, o delicioso e tradicional bolo-de-domingo, doce de melindres, queijadinha, doce de toucinho (...)

"Fausto se atirou, desde logo, numa espécie de libertação pantagruélica, sobre a enorme mesa que a senhora do Chico, assistida por um casal de cozinheiros de escolha, havia preparado para nós .

Lombo com torresmos; capão com farofa, feijão-de-tropeiro com carne-de-sol; empada de galinha; luminárias e canudos de doce-de-leite; fios-de-ovos; laranja em calda e requeijão do Urucuia. Nunca louvaríamos bastante o tato e o bom gosto do casal Chico Pinheiro de não ter preparado um só prato que não fosse da região, evitando-nos o suplício das maioneses e outras iniciativas alienígenas com que, erradamente, nos brindam certos amigos do interior”.

Em outubro de 1949, em reportagem da revista "O Cruzeiro", referindo-se à comida da

Pensão de Dona Iaiá, registrou-se:

“...é com um certo remorso, perante as sacrificadas populações paulista e carioca, que revelamos que qualquer visitante pode comer na pensão de D. Iaiá Roquete Franco, treze pratos diferentes em cada refeição, pagando por isso vinte cruzeiros por dia, incluindo pousada. E quereis saber o que vem à mesa ? - lombinho de leitão assado, tutu bem temperado, arroz de forno, filé "mingnon” com ovos, picadinho, legumes, bife com cebola, lingüiça de porco, feijão branco...e para sobremesa, doce de coco com leite. Na verdade, D. Iaiá Roquete, além de sua simpatia pessoal, cativa os estranhos com suas mesas milionárias de paladares. A sua pensão é assim uma espécie de departamento de propaganda de Paracatu”.

Ao analisar o texto apresentado, verifica-se a presença de trechos que demonstram estreita ligação entre a hospitalidade e a gastronomia na cidade de Paracatu e que o ritual de recebimento de hóspedes, já naquela época (1949), obedecia ao mesmo rigor de hoje, na produção de eventos sociais e festas sofisticadas.

As passagens "A senhora do Chico, assistida por um casal de cozinheiros de escolha” e “o tato e o bom gosto do casal Chico Pinheiro” revelam refinamento no trato com hóspedes.

Verifica-se, ainda, que dentre as iguarias oferecidas na Paracatu antiga, muitas estão em evidência e fazem parte da autêntica cozinha mineira dos dias atuais, tais como: feijãode-tropeiro, lombo com torresmos, lombinho de leitão assado, tutu bem temperado, arroz 
de forno, filé mignon com ovos picadinhos, legumes, bifes com cebola, lingüiça de porco. Muitas dessas delícias podem ser saboreadas em restaurantes de comida típica mineira, espalhados pelo Brasil a fora, e tornaram-se uma identidade para Minas Gerais.

O bolo de domingo é uma iguaria feita com fubá de arroz, tradicionalmente servida aos domingos no café da manhã em Paracatu. Tem ritual de preparação e a receita é passada de geração em geração. Este bolo é muito apreciado pelos paracatuenses, a ponto de ser merecedor de poesia. No seu livro de poemas: Paracatu um passeio no tempo, Zenóbia Loureiro (1993) apresenta o poema dedicado ao "Bolo de Domingo”:

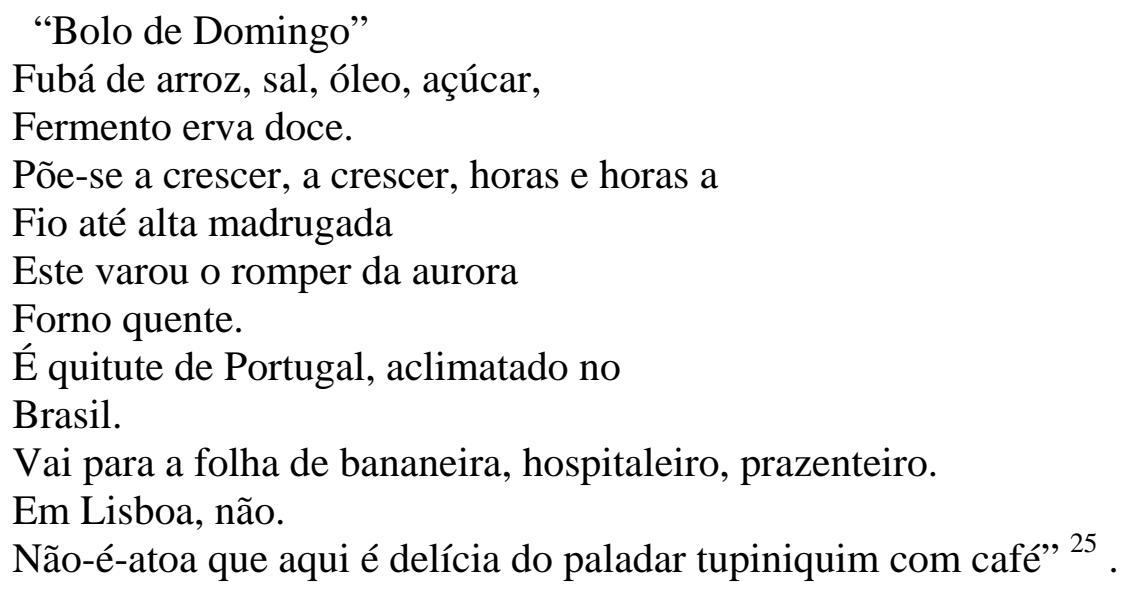

A idéia de hospitalidade na cidade de Paracatu confunde-se com sua própria história. Assim como no passado o incremento do comércio e das viagens motivou o surgimento das primeiras acomodações. Paracatu já nasceu sob o signo da hospitalidade ao ser palco do "arranchamento" das Bandeiras do ciclo do ouro e das boiadas do ciclo do couro. Nessa encruzilhada, acredita-se que houve o surgimento das primeiras acomodações para acolhimento desse contingente humano.

Ao longo de seus séculos de história, Paracatu experimentou a condição de anfitriã ao acolher viajantes estrangeiros e a eles manifestar o seu refinamento no ato de receber e na arte de agradar ao visitante.

25 LOUREIRO, Zenobia Vilela (1993) Poema extraído do livro: Paracatu um passeio no tempo ed da autora, 1993. 
O gesto da hospitalidade paracatuense perpassa pelo regionalismo brasileiro que retratou a vivência do sertanejo por meio de obras como: De Volta ao Sertão: Afonso Arinos e o Regionalismo Brasileiro. Esta obra, citada anteriormente, retrata a hospitalidade paracatuense manifestada através do ritual de recebimento, bem como a hospitalidade entre as famílias. Dessas manifestações vivenciadas na segunda metade do século XX, a comunidade paracatuense guarda até hoje muitas recordações.

Apesar do isolamento em que viveu depois de declaradas exauridas as minas de ouro de aluvião, Paracatu pôde manter viva e aperfeiçoar sua cultura, acumulando vivências adquiridas das mais diversas origens que se transformaram em tradições.

Aurélio $^{26}$, em seu dicionário de língua portuguesa, define o termo tradição como “transmissão de lendas, atos de idade em idade, geração em geração [...] transmissão de valores espirituais através de gerações [...] conhecimento ou prática resultante de transmissão oral ou de hábito inveterados”.

A cidade de Paracatu hoje avança em termos de tecnologia, mas orgulha-se do seu passado cultural. São reminiscências de momentos consagrados pela profusão de culturas que deram origem a seus valores e lendas. Esses valores e lendas são percebidos no desejo dos paracatuenses de verem divulgadas essas tradições de Paracatu: tapuiada, caretada, festas religiosas tradicionais, culinária tradicional, o carnaval antigo e também conservação da arquitetura que testemunha uma época remota.

Tradições culturais são temas que vêm sendo trabalhados por diversos profissionais como historiadores, jornalistas e de interesse da sociedade de modo geral. Por isso, profissionais envolvidos com turismo têm sido freqüentemente alvo de profissionalização por parte de municípios turísticos.

Paracatu conta com expressivo potencial turístico. (diversas cachoeiras, quedas d’água, balneários e outros); arquitetura barroca (casarios antigos, templos religiosos, museus); boa estrutura hoteleira e de acessibilidade além de localização, próxima a grandes centros consumidores.

\footnotetext{
${ }^{26}$ FERREIRA, Aurélio Buarque de Holanda
} 


\section{CAPÍTULO 3 - TURISMO EM PARACATU}

\section{1 - O Despertar do Turismo em Paracatu}

A comunidade Paracatuense está dando os primeiros passos no sentido de desenvolver o turismo local, com manifesto apoio do poder público. Para tanto, vem promovendo encontros que contam com a participação da comunidade.

Em reunião realizada em 27 de junho de 2003, no SESC/LACES de Paracatu, Vanda Lacerda, mestre em turismo pela universidade de Baleares (Espanha), e consultora do SEBRAE/MG, apresentou o Plano Nacional de Turismo, desenvolvido pelo governo federal.

Na ocasião, Vanda Lacerda falou sobre a importância da formação de um circuito turístico regional tendo Paracatu como pólo, ressaltando a relevância da qualificação profissional para o seguimento turístico.

A comunidade paracatuense tem participado das reuniões sistemáticas promovidas pela ADESP-Agência de Desenvolvimento Econômico e Social de Paracatu. Dentre as atividades desenvolvidas no sentido de impulsionar o turismo na cidade de Paracatu podese citar:

- Criação de um Balcão de informações ao Turista;

- Sensibilização e conscientização do potencial turístico;

- Programa de apoio ao artesãos;

- Organização da infraestrutura da cidade, com a intenção de receber o turista;

- Criação do Circuito Regional de Turismo.

Muitas dessas iniciativas poderão vir a se integrar às políticas públicas de turismo do município. 
Em setembro de 2003, foi realizado o I Fórum Integrado de Desenvolvimento Sustentável. Realizado pela Agência de Desenvolvimento Econômico e Social de Paracatu-ADESP, em parceria com a Interfórum Global - Intercâmbio de Desenvolvimento Sustentável, com o objetivo de promover mudanças e impactos nos índices de desenvolvimento do município, conforme a citação abaixo:

"Para que um município se desenvolva de forma consciente e equilibrada é preciso planejamento e a participação efetiva da comunidade. Discutir o que é necessário fazer para promover o desenvolvimento econômico sem deixar de levar em conta os impactos ambientais e sociais é o principal objetivo do I Fórum de Desenvolvimento Sustentável, em Paracatu, noroeste de Minas Gerais (...) estamos mostrando as possibilidades de desenvolvimento, potencializando a energia da sociedade de Paracatu, construindo as parcerias com o poder público e sociedade e, principalmente, vamos implementar a Agenda 21 local de desenvolvimento de Paracatu”27.

Dentre os assuntos tratados no Fórum, foram citados: cultura regional, riqueza cultural material e imaterial; conhecimento tradicional, propriedade intelectual, produção artesanal e folclore; sítios históricos e populações tradicionais; circuito turístico local e regional; Plano Diretor de Turismo Sustentável (PDITS) e a terceira idade como guardiã do patrimônio histórico cultural e agente promotora do desenvolvimento humano sustentável.

Entendem-se por políticas públicas, as ações que o governo desenvolve visando atender os interesses da sociedade de modo geral.

No livro Turismo, políticas públicas e relações internacionais, (2003:30-35), Margarita Barreto, Raúl Burgos e David Frenkel afirmam que:

"No turismo, o papel das políticas públicas deveria ser o de propiciar o desenvolvimento harmônico dessa atividade. Cabe ao construir a infra-estrutura de acesso e a infra-estrutura básica urbana - que também atende à população local - e prover uma superestrutura jurídico-administrativa (secretarias e similares) cujo papel é planejar e controlar que os investimentos que o estado realiza - que permitem o desenvolvimento da iniciativa privada, encarregada de construir os equipamentos e prestar os serviços - retornem na forma de benefícios para toda a sociedade.”

Os autores comentam que muitos dos conflitos gerados entre interesse público e turismo devem à falta de clareza no processo de criação de políticas públicas e que os

\footnotetext{
${ }^{27}$ Artigo referenciado em Cidades On-Line, seção notícias locais, Paracatu, sob o título "Fórum de Desenvolvimento Sustentável mobiliza Paracatu” divulgado no site http://www2.uol.com.br/forum_sustentável_des.htm , acesso em 9/11/2003. essas informações também foram fornecidas em meio magnético (disquete) pelo senhor Artur, representante da ADESP.
} 
impactos negativos do turismo apontados por Geógrafos e Antropólogos poderiam ser prevenidos:

- Se o espaço é ocupado de forma indevida, é porque faltaram políticas públicas adequadas na área da construção civil, faltou um plano-diretor ou faltaram fiscalização dos órgãos do Estado e meios para fazer cumprir as leis.

- Se os empreendimentos turísticos estão contaminados, poluindo rios e mares, prejudicando o meio ambiente natural, é por falta de políticas públicas na área ambiental (rede de esgoto tratamento de efluentes).

- Se o turismo gera subempregos, é porque falta uma política trabalhista adequada.

Paracatu acha-se, hoje envolvida com os trabalhos preliminares de implantação do turismo no município ${ }^{28}$.

Ao desenvolver o Plano Diretor de Turismo Sustentável, imagina-se que o município de Paracatu está no caminho ideal para o desenvolvimento do turismo local e com isso demonstra compreender a relevância da política pública voltada para o turismo.

${ }^{28}$ A Prefeitura de Paracatu desenvolve as políticas públicas locais normais. 


\section{CAPÍTULO 4 - CONSIDERAÇÕES FINAIS E SUGESTÕES}

O trabalho ora apresentado mostra que o gesto da hospitalidade é conhecido desde a Antigüidade e vem sofrendo transformações ao longo dos tempos.

Em Paracatu, segundo as fontes de pesquisa consultadas, o fenômeno da hospitalidade remonta aos antepassados familiares, revelados por de diversas práticas sociais, como a valorização dos relacionamentos interpessoais, tanto na família como na igreja e em outros seguimentos da sociedade.

O termo hospitalidade vem ganhando destaque no que se refere à cidade de Paracatu, principalmente porque mantém viva a arte de bem receber, peculiar aos habitantes da região e também por ser parte integrante da famosa culinária mineira conhecida pelo irresistível sabor dos pratos típicos. Dentre os principais "produtos da terra”, alguns se destacam o tradicional bolo de domingo, a cachaça de Paracatu e o delicioso pão de queijo, conhecido e aceito não apenas em Minas Gerais, mas em outras localidades brasileiras.

Paracatu demonstra tradição em termos de valorização da família, mas também acompanha os novos tempos em termos de tecnologia. Essa modernidade é percebida pelas características da cidade no que diz respeito a sua infraestrutura e o acolhimento a grandes empresas e projetos visando ao desenvolvimento local.

Essas manifestações aliadas ao expressivo patrimônio turístico e cultural reúnem condições importantes para que a cidade de Paracatu possa sustentar a condição de cidade hospitaleira, adquirida desde os seus tempos de Vila do Paracatu do Príncipe.

Ao longo do trabalho, percebeu-se o quanto o gesto da hospitalidade é importante para o turismo. Sendo assim, sugere-se aos paracatuenses vincular sua fama de 
hospitaleiros, considerando-se a evolução do seu conceito, ao desenvolvimento do turismo de modo a agregar valor ao produto turístico que se pretende desenvolver.

Sugere-se ainda:

- Capacitar os profissionais envolvidos no atendimento a turistas, inclusive os gestores (gerentes e administradores);

- Capacitar para a hospitalidade profissional e o turismo também funcionários dos quadros da Prefeitura, (uma vez que a hospitalidade profissional envolve o setor público por meio de políticas voltadas para o turismo);

- Criar associações específicas para os setores de hospitalidade e turismo. Essa medida é importante porque todos os associados, no caso empresas do ramo, têm os mesmos interesses e como entidade a associação se fortalece para fazer reivindicações necessárias junto aos órgãos competentes. 


\section{REFERÊNCIAS BIBLIOGRÁFICAS}

BARRETO, Margarita. (Coord.). Borges, Raul e FREENKEL, David: Turismo, políticas Públicas e Relações Internacionais. São Paulo: Papiros, 2003. (Coleção Turismo).

BERTRAN, Paulo. História da Terra e do homem no Planalto Central: Eco-história do Distrito Federal. Brasília: Verano, 2000.

Bíblia Sagrada, Ave Maria (Revisão)Frei João José Pedrei de Castro, 150. ed. São Paulo, 2002.

CASTELLI, Geraldo. Excelência em hotelaria: uma abordagem prática. , 4. ed. Rio de Janeiro: Qualitymark, 2002.

DIAS, Célia Maria de Moraes. (Org.). CANTON, Antonia Marisa; MONTANDON, Alain; BAPTISTA, Isabel; GRINOVER, Lucio; CAMARGO Luiz Octávio de Lima; MAFFESOLI, Michel; PAULA, Nilma Morcerf de; CRUZ, Rita de Cássia Ariza da e Matheus, Zilda Maria. Hospitalidade: Reflexões e Perspectivas. São Paulo: Manole, 2002.

LOUREIRO, Zenobia Vilela. Paracatu: um passeio no tempo, 1993 ed. da autora, Paracatu, 1993.

FERREIRA, Aurélio Buarque de Holanda. Novo Dicionário da Língua Portuguesa, 2. ed. Rio de Janeiro, 1986.

MELLO, Oliveira. As Minas Reveladas: Paracatu no Tempo. 2. ed. Prefeitura Municipal de Paracatu, 2002.

Paracatu, ed. da Prefeitura Municipal de Paracatu, 2002. . De Volta ao Sertão. Prefeitura Municipal de Paracacatu, 1975. . Minhas Opiniões. E as Suas? Paracatu. Academia de Letras do Nordeste de Minas do Noroeste de Minas, 1998. 
MURTA, Stela Maris; ALBANO e Celina, (org). Interpretar o Patrimônio: um exercício do olhar. Belo Horizonte: ed. UFMG. Território Brasilis, 2002.

PIRES, Mário Jorge. Raízes do Turismo no Brasil. 2. ed. Manole: São Paulo, 2002.

TRIGO, Luiz Gonzaga Godoi. Turismo e qualidade: Tendências Contemporâneas. São Paulo: Papiros, 1993.

RODRIGUES, Francisco, Flávio A.; LEAL, Maria Leonor de M. S. e HARGREAVES, Lourdes. Qualidade em prestação de serviços. Rio de Janeiro: SENAC/DN/DFP, 1997.

YAZIGY, Eduardo. Turismo: uma esperança condicional. 2. ed. Global: São Paulo, 1999.

A Pequena Hotelaria e o Entorno Municipal: Guia de montagem e administração. 2. ed. Contexto: São Paulo, 2000.

\section{FONTES DIVERSAS}

ALBERnAZ, Lavoiser. Morro do Ouro Ambição e Agonia: CPCE/UNB, 1992. (fita de Vídeo em videotape - fita magnética para gravação em videotape).

\section{DISQUETES}

Agência para Desenvolvimento Econômico e Social de Paracatu - ADESP, Fórum de Desenvolvimento Sustentável, 2003, Paracatu - Implantação da Agenda 21 Local.

Secretaria de Indústria, Comércio e Turismo de Paracatu. Relatório de Execução de Serviços, 2001, Paracatu - Levantamento do acervo as belezas naturais do município de Paracatu.

\section{SITES}

Grupo Editorial Armonia. Mujer em Armonia, Disponível na Internet em http://www.terra.com.mx/MmuejerEnArmonia/articulo/115713/htm, acesso em 16/9/2003.

Associação de Imigrantes. Dever da Hospitalidade, Disponível na Internet em http://imigrantes.no.sapo.pt/indexHospital.html, acesso em 17/9/2003. 
Universidade Anhembi. Morumbi. Algumas Considerações a respeito da Hospitalidade, ${ }_{2} \quad$ Disponível na Internet em http://www..anhembi.br/portalnossa_u/cursos/pos-graduacao/pos-

strictuensu_consideracoes.htm, acesso em 17/9/2003.

Associação Mineira do Ministério Público, 16 . Seção Regional - Paracatu. Características, Disponível na em <http:/www.ammp.org.br/cidadessede.asp?secao=16>, acesso em 1/10/2003.

NOGUEIRA, Fabiana. “Cidade” é tema de pesquisa, Intercom Virtual, Minas Gerais, 2003, Disponível na Internet em http://www.fca.pucminas.br/noticias/0609fabiestudos.htm>

9/11/2003.

Cidades On-Line - Paracatu. "Fórum de Desenvolvimento Sustentável mobiliza Paracatu”, UOL, Disponível no site <http://www2.uol.com.br/forum_sustentável_des.htm , acesso em $9 / 11 / 2003$.

Prefeitura Municipal. Bem-Vindo ao Município de Paracatu Minas Gerais Brasil. http://www.ada.br.Paracatu/htm?BVINDO.htm, acesso em 1/10/2003. 


\section{ANEXOS}
A - Localização do município
B - Fotografias: Aspectos da cidade ${ }^{29}$
C - Folders sobre Paracatu.

${ }^{29}$ Fotografias: Marlene Galvão, nov/2003. 